\title{
LIQUIDITY RISK AND REGULATION IN THE ORGANIZATION OF THE ISLAMIC COOPERATION (OIC) BANKING INDUSTRY
}

\author{
Syajarul Imna Mohd Amin ${ }^{*}$, Aisyah Abdul-Rahman ${ }^{1,2}$ and \\ Nurhafiza Abdul Kader Malim ${ }^{3}$ \\ ${ }^{1}$ Faculty of Economics and Management, Universiti Kebangsaan Malaysia, \\ 43600 UKM, Bangi, Selangor, Malaysia \\ ${ }^{2}$ Institute of Islam Hadhari (HADHARI), Universiti Kebangsaan Malaysia, \\ 43600 UKM, Bangi, Selangor, Malaysia \\ ${ }^{3}$ School of Management, Universiti Sains Malaysia, \\ 11800 USM Pulau Pinang, Malaysia \\ *Corresponding author: imna@ukm.edu.my
}

\begin{abstract}
The recurring crises have evidenced poor liquidity risk management and ineffective regulation in banking. Consequently, banking regulations have undergone continuous reforms to bolster stability in the banking system. Nonetheless, theoretical and empirical evidence provide conflicting results that warrant comprehensive research, particularly for emerging Islamic banking. This study examines the role of banking regulation on the liquidity risk of 245 conventional banks and 68 Islamic banks from selected 14 Organization of the Islamic Cooperation (OIC) from 2000 to 2017 utilising the dynamic panel GMM (generalised method of moments) technique. We measure liquidity risk using the Net Stable Funding Ratio (NSFR) and the total financing-to-total deposits and short-term funding (LDEP). Meanwhile, the regulatory measures are asset restriction $(A R)$, private monitoring (PM), supervisory power $(S P)$ and capital requirements (CR). The findings suggest that regulation has a limited impact on bank liquidity risk. The CR supports the value creation of regulation through the reduction in banks' liquidity risks, while PM and SP are agency costs of regulation that lead to higher liquidity risks.
\end{abstract}

Publication date: 10 December 2021

To cite this article: Amin, S. I. M., Abdul-Rahman, A., \& Malim, N. A. K. (2021). Liquidity risk and regulation in the Organization of the Islamic Cooperation (OIC) banking industry. Asian Academy of Management Journal of Accounting and Finance, 17(2), 29-62. https://doi.org/10 .21315/aamjaf2021.17.2.2

To link to this article: https://doi.org/10.21315/aamjaf2021.17.2.2

(C) Asian Academy of Management and Penerbit Universiti Sains Malaysia, 2021. This work is licensed under the terms of the Creative Commons Attribution (CC BY) (http://creativecommons. org/licenses/by/4.0/). 
The impact of $C R$ is lower on liquidity risk in Islamic banking than conventional ones, probably due to limited Islamic liquidity risk management facilities. Thus, regulators should strengthen Islamic liquidity risk instruments and markets to facilitate Islamic banking growth.

Keywords: bank regulation, supervision standards, liquidity risk, Islamic banks, GMM

\section{INTRODUCTION}

Technology advancement, financial innovation, globalisation and deregulation have dramatically changed the banking sector throughout the decades ( $\mathrm{Li}$, 2019). Banks' becoming opacity and complexity following financial reforms such as financial technology and accessibility, bank privatisation and structural transformation of the banking system have posed liquidity risk management a challenging issue in the banking industry. Without prudent liquidity risk management, banks may expose to insolvency and bankruptcy problems in which the effect can be contagious and end up collapsing the entire financial systems (Diamond \& Rajan, 2000, 2005; Berger \& Bouwman, 2009), like the documentations of many banking failures in the recent global crisis in 2008. In this regard, liquidity risk management has become the top priority agenda within the policy circle (Otero González et al., 2018). It is argued that the banking regulations and supervision are the panacea to govern and monitor the risk-taking behaviour in the banking industry for financial stability.

Banks have long been a market maker in economic systems through their core function as liquidity creation for households' consumption, firms' investment, entrepreneurship, financial markets and economic growth. Accordingly, a robust regulatory and supervisory framework for the banking system is crucial to protect investors, financial markets and the real economy. More importantly, regulation measures are imperative to ensure prudent risktaking incentives that lead to meaningful banking growth. For instance, capital requirements induce banks to embark on riskier activities due to the tradeoff of 'franchise value' effect (Keeley, 1990). High-capitalised banks tend to engage in riskier lending to increase profitability to compensate for the higher cost of equity (compared to deposits). Similarly, the financial fragility structure (i.e., low capital) commits banks to practice prudent lending activities to ensure sufficient liquidity in meeting both depositors' and borrowers' needs. In contrast, the 'equity-at-risk' effect and deposit 'crowding out' hypotheses predict that more capital reduces excessive risk-taking. High-capitalised banks with higher riskbearing capacity are exposed to greater capital losses, thus encouraging banks to practice prudent (low risk) banking activities, conjecturing an inverse capital- 
risk relationship. Likewise, banks with high capital (crowding out deposits) have less liquidity to fund illiquid assets (loans), thus reducing bank risk-taking behaviour. Similarly, asset restrictions limit risk diversification (Barth et al., 2004), indirectly exposing banks to higher risk. While fewer restrictions promote competition and risk-taking incentives due to the 'franchise value' effect (Keeley, 1990). In a similar vein, supervisory power is expected to discipline risk attitude based on 'Public Interest' theory, which postulates the important role of government in regulating banks to preserve the public interest. Whereas 'Private Interest' theory suggests that politically connected supervisors could increase risk in banking as they tend to pursue private or political interest instead of public interests (Shleifer \& Vishny, 1998). Concerning private monitoring, it is imperative to promote prudent banking (Barth et al., 2013), but informational asymmetry may prevent effective monitoring by the public (Brandao-Marques et al., 2018).

Previous literature examined the impact of regulation on bank risk in several dimensions, namely capital (Fungáčová et al., 2017, Holod et al., 2020), activity restrictions (Mohsni \& Otchere, 2018), supervision (Fernández \& González, 2005; Tabak et al., 2016), and private monitoring (Brandao-Marques et al., 2018), yet the findings are inconclusive. While the documentations focus on bank risk in general, little evidence is found on how bank regulations affect liquidity risk, especially in Islamic banking. We believe this research of interest offers policy implications for Islamic banking concerning the current infancy state of the industry. The dearth of empirical research in Islamic baking motivates this study to explore the regulation-liquidity issue in the Organization of the Islamic Cooperation (OIC) members' countries. The OIC countries are the dominant markets offering Islamic banking services, which account for more than $90 \%$ of global Islamic banking assets (Standing Committee for Economic and Commercial Cooperation of the Organization of the Islamic Cooperation (COMCEC), 2018). Given the industry's astonishing growth, examining the liquidity issue is critical for the sustainability of Islamic banking in OIC countries. Besides, it is vital to examine the role of bank regulations and supervision on the liquidity practice in OIC member countries that exhibit dual banking systems and where Islamic banking is more pronounced. Moreover, the economies of OIC countries are highly dependent on the banking market as a source of financing due to the less developed capital market. Evaluating liquidity risk is critical for Islamic banks in OIC countries as they are prone to liquidity gaps in the absence of robust Shariah-compliant hedging and money market instruments needed to allocate cash efficiently.

The liquidity issue is more critical for Islamic banks due to several constraints such as shallow money markets and limited liquidity risk management 
tools (Amin et al., 2017). Islamic banks are also restricted by Shariah principles (i.e., free from riba, maysir, non-Shariah compliant activities), which affects their business model and risk profile differently from conventional banking. Besides boosting profitability, Islamic banks must achieve Maqasid Shariah through value-based intermediation to promote economic and social equitability. The embarking on social and economic ventures has distinguished their balance sheet structure compared to the traditional ones. Concerning the regulatory and legal environments of the Islamic banking industry, Alam et al. (2018) emphasised that Islamic banking regulations are still in deficiencies. For instance, the proposed regulatory measures in Basel III have received many criticisms for their failure to address the risk associated with Islamic banking. Although the Islamic Financial Services Board (IFSB)'s standards (IFSB, 2008; 2012; 2013) have improvised the standards tailored for Islamic banking, the implementation is non-mandatory and lacks international uniformity. Moreover, Alam (2013) and Alam et al. (2018) highlighted that many dual banking system countries still practice a single regulatory framework based on conventional regulations and legal environments. Against this background, Islamic banking provides a suitable case for examining the regulation-liquidity risk relationship.

This study aims to analyse the regulation-liquidity risk relationship in the OIC banks from 2000 to 2017. We applied the indices for activity restrictions (AR), private monitoring (PM), supervisory power (SP), and capital requirements (CR) constructed based on Barth et al. (2001, 2006, 2008, 2013) survey to measure the regulatory and supervisory framework. We used total financingto-total deposits and short-term funding (LDEP) and the Net Stable Funding Ratio (NSFR) of Basel III to capture liquidity risk in banking. We examined the effect of regulation on liquidity risk by using the dynamic panel system GMM (generalised method of moments) model to resolve the issues of endogeneity, heteroscedasticity and serial correlation. The key findings indicate that the effect of regulation on liquidity risk of Islamic and conventional banks in OIC countries is not uniform based on regulatory policies and liquidity risk measures. The results reveal that regulation has little effect on liquidity risk in banking. In general, we found that capital requirements create value by decreasing liquidity risk while private monitoring and supervisory power incur costs that lead to higher liquidity risk. The impact of $\mathrm{CR}$ is lower on liquidity risk in Islamic banking than conventional ones.

We contribute to the existing banking literature in threefold. First, we testified to the regulation-risk taking theory in the context of liquidity risk. Second, we focused the study on Islamic banking in OIC countries which represent emerging economies. Third, we extend previous literature by comparing 
the regulation-liquidity risk relationship using the current liquidity risk measure (NSFR) and traditional liquidity risk measure (LDEP).

\section{LITERATURE REVIEW}

The role of regulation on banking has two sides of coins, either value creation or cost to the bank. Most previous studies examined the impact of regulation on banking in different aspects, including efficiency, competition and productivity, while only a few studies focus on bank risk. Despite these various aspects, we include the studies that may indirectly affect bank risk-taking behaviour. The following discussion reviews relevant literature regarding four banks' regulatory and supervisory measures: capital requirements, official supervision, asset restrictions and private monitoring. These regulation measures are the main policy concerns in promoting the prudent and stability of banking systems.

\section{Capital Requirements}

Capital requirements are the minimum regulatory capital required for a bank to buffer against its risk-weighted assets (Laeven \& Levine, 2009). It ensures banks maintain adequate capital to absorb losses resulting in systemic problems (Deli $\&$ Hasan, 2017). From the theoretical perspective, capital requirements belong to two points of view (Hellmann et al., 2000; Repullo, 2004), namely, "franchise value" effect and "equity-at-risk" effect.

The "franchise value" theory predicts a positive relationship between capital and bank risk (Keeley, 1990). Capital encourages banks to take more risks to compensate for the cost of "franchise value". In this sense, banks that bear the cost of equity and loss of franchise value would have higher incentives to provide riskier lending to boost profitability. It is consistent with the risk absorption hypothesis, which postulates that high capitalised banks tend to have better riskbearing capacity and allow them to embark on riskier investments (Bhattacharya \& Thakor, 1993; Coval \& Thakor, 2005; Hellmann et al., 2000; Von Thadden, 2004). Similarly, the "financial fragility" hypothesis (Diamond \& Rajan, 2000; Fungáčová et al., 2017) also shows a positive capital-risk relationship. In support of this theory, Altunbas et al. (2018) showed a positive effect of capital on credit and insolvency risk involving banks in 61 advanced and emerging economies.

Meanwhile, the "equity-in-risk" theory expects a negative relationship between capital and bank risk. Capital discourages risk-taking incentives due to the "equity-at-risk". The risk-based capital would expose the bank owners to 
capital losses if the risky investments were getting awry. In other words, the upside gains of high capitalised banks would enjoy in taking a greater risk will be countervailed by a greater probability of capital losses. Therefore, capital requirements are believed to be the appropriate regulatory tool to align the bank owners' interests with depositors and borrowers. As a result, the bank will undertake prudent decisions on lending activities and promote better financial stability (Barth et al., 2013). On the same note, the 'deposit crowding-out' hypothesis (Gorton \& Winton, 2017) also provides a similar argument. The modelling framework by Bolt and Tieman (2004) shows that stricter capital requirements force banks to tighten credit approval criteria, resulting in careful lending and lower risk-taking. The study provides mathematical evidence supporting the effectiveness of risk-adjusted regulation and suggests banks allocate higher capital buffer than imposed by the financial authorities. The negative capital-risk taking relationship theory is also empirically evidenced in the U.S. (Holod et al., 2020) and German banks (Berger et al., 2016) and with greater bank-borrowers' relationship, which decreases the asymmetric information problems. Likewise, Fernández and González (2005) also support the theory using 29 countries.

\section{Supervisory Power}

Supervisory power refers to regulatory monitoring in bank operations to safeguards against bank panic and reduces excessive risk-taking behaviour (Barth et al., 2004). The economic reasoning of granting broad supervisory power is several (Leaven \& Levine, 2009). First, bank activities are costly and difficult to supervise, leading to very little monitoring at the bank level that results in sub-optimal performance. Second, market imperfection due to asymmetric information exposes banks to contagious bank runs. Third, the practice of a deposit insurance scheme creates a moral hazard that incentivises banks to take more risk and less monitoring by depositors. Fourth, it also enhances corporate governance and competitiveness in banking). Against this background, official supervision is critical to prevent the bank from excessive risk-taking behaviour and improve bank performance and stability.

Based on the economic theories of regulation, government intervention via regulation and supervision is predicted to provide two conflicting outcomes (Posner, 1974; Barth et al., 2006; 2013). Beck et al. (2006) discussed official supervision under two alternative theories: Public Interest and Private Interest hypotheses. The Public Interest theory holds that regulation is necessary because the government aligns with the public interests and regulates banks to promote efficiency and alleviate market failures. The regulation provides corrective 
measures against problems associated with various sources of market failure and market imperfection. It holds that regulators are independent, rational, and well-informed, making any regulatory policies immune from the pressure of interest groups or informational limitations. Thus, regulation encourages socially optimum resource allocation, economic and banking system stability. By requiring minimal quality standards such as those pillars proposed in Basel Accords, asset allocation rules, and interest rate ceilings, the regulation will circumvent excessive risk-taking behaviour and solve market inefficiencies in the banking industry. This theory suggests that supervision is negatively related to bank risk. It assumes powerful supervisors could discipline banks; promote good governance and financial stability.

On the contrary, the Private Interest theory predicts that regulation is often used to serve the interests of the few and not the entire society, thereby hindering banking performance. It assumes that regulation fails to maximise social welfare but is instead pursues on self-interest. The interest groups may directly or indirectly involve in the decision-making process and exploit the lawmaker. The regulation is designed to benefit the interest groups to secure power and positions and obtain future career opportunities in the involved sector (Stigler, 1971). It is believed that regulatory issuance will only serve the interest of the involved sector at the expense of consumer welfare. In the end, banking regulation will favour laxity and low-cost supervisory systems that incentivize excessive risk-taking behaviour in banking. Especially in politically connected supervision, supervisors may misuse their power to force banks to provide financings in easier terms or create obstacles to specific groups in favour of their political agenda (Shleifer \& Vishny, 1998). Under this influence, banks may undertake sub-optimal decisions that will not improve bank development. This theory hypothesises a positive relationship between supervision and bank risk.

Previous studies have evidenced mixed findings. For instance, the seminal work of Barth et al. (2001) found that increases supervision reduces bank performance and increases bank risk. The findings are consistent in their later study, especially in emerging economies (Barth et al., 2003). However, Barth et al. (2006) showed an insignificant effect of supervision on bank performance. Interestingly, their later study in 2013 found that strict supervisory improve bank efficiency, particularly for countries where politics does not influence supervision (Barth et al., 2013). Another study by Fernández and González (2005) found that powerful supervision in financial auditing and reporting systems decreases risk-taking incentives for publicly traded banks in 29 countries. Focusing on developing countries, Cubillas and González 
(2014) reported that banks tend to indulge in riskier investments without rigid supervision due to intense competition. Similarly, Tabak et al. (2016) documented that official supervision reduces insolvency risk.

\section{Activity Restrictions}

Activity restrictions measure regulatory limitations on bank involvement in securities, real estate, insurance and owning non-financial firms. Barth et al. (2013) refer to these activities as the key forces influencing risk-taking incentives. Keeley (1990) opined that fewer activity restrictions intensify competition, forcing banks to take more risk to compensate for diminishing franchise value. Further, Barth et al. (2004) highlighted several justifications for enforcing activity restrictions. First, investing in diverse asset portfolios like a universal bank exposes banks to a conflict of interest and encourages banks to take higher risks. Second, complex and dominant banks are difficult to discipline as they gain increasing political and economic power. Finally, as they become a large financial conglomerate, competition and efficiency will deteriorate. Therefore, it is expected that asset restrictions are inversely related to bank risk. Barth et al. (2004) also provided contradictory reasons for supporting fewer restrictions on banking activities due to obtaining the economies of scales and scope, increasing franchise values, improving service quality, and promoting assets diversification. Therefore, activity restrictions could limit banks' capability to diversify risks that expose banks to high- risk exposure.

The empirical findings on activity restrictions-risk relationships are inconclusive. Brandao-Marques et al. (2018) added that restricting banks from engaging in a diverse array of assets decreases risk-taking with increased government support. They concluded that reducing complexity in banking improves market discipline on banks due to better monitoring. Similarly, Fernández and González (2005) indicated that activity restrictions restrict banks from taking more risk, in the case of countries with poor supervision, i.e., underdeveloped auditing and accounting systems. On the other hand, activity restrictions encourage more risk- taking (Barth et al., 2006; Laeven \& Levine, 2009), reduce efficiency (Barth et al., 2013), and increase bank fragility (Barth et al., 2006). Besides, Liu et al. (2012) discovered a positive activity restrictions-risk relationship for banks in Southeast Asian countries. Beck et al. $(2006$; 2013) showed that strengthening activity restrictions increases banking risk with intense competition in a broader context. Surprisingly, Mohsni and Otchere (2017) reported that restrictions incentivise Canadian banks to take more risk, while the U.S. banks tend to engage in less risky investments. 


\section{Private Monitoring}

Private monitoring is the governance and monitoring ability of private investors, auditors and the public on banks through information disclosures. According to Barth et al. (2013), the private monitoring measures the requirements of:

1. Obtaining certified audit and rating from international-rating agencies;

2. Disclosing consolidated annual reports including off-balance sheet items, risk management activities, unpaid interest/principal in the income statement;

3. Allowing subordinated debt as part of capital;

4. Having directors who are legally liable for any erroneous and misleading information disclosure; and

5. Having deposit insurance policy.

There are disagreements on the proposition of private-sector monitoring vs. supervision by the ruling government (Barth et al., 2004). The proponent of private monitoring is that official supervisors would be less effective in supervising and disciplining banks since they may act based on their interest as they have no ownership stake in banks than private stakeholders (like depositors and shareholders) (Shleifer \& Vishny, 1998). Moreover, based on the Private Interest hypothesis, dominant banks may greatly influence pressure politicians, affecting supervisory oversight and enforcement. Consequently, private monitoring is imperative to discipline and promote prudent banking (Barth et al., 2013). Nevertheless, there is also a countervailing argument on the effectiveness of private monitoring, especially for countries that are characterised by underdeveloped capital markets, accounting standards and legal systems. The practice of private monitoring would be less effective due to informational barriers (Barth et al., 2004) and government support to banks (Brandao-Marques et al., 2018). Furthermore, the increasing complexity of banks nowadays may cause reliance on private sector monitoring challenges even in developed countries. Outsiders would face difficulties in assessing the increasing level and types of risk perceived by banks (Brandao-Marques et al., 2018). In this regard, private monitoring could lead to the exploitation of depositors and inadequate bank monitoring (Barth et al., 2004).

The documentation of empirical evidence on private monitoring can be found in several aspects. Focusing on Bangladeshi banks, Zheng et al. (2017) reported that private monitoring via bank disclosures has a limited role in improving credit risk (measured by bad loans). For cross-country research, Delis et al. (2011) found that private monitoring increases banks' productivity in 
22 transition countries. Considering the worldwide database, Barth et al. (2013) discovered that private monitoring enhances bank efficiency, while BrandaoMarques et al. (2018) found that increasing private monitoring is preferable to reduce risk attitude in banking.

\section{Literature Gap Analysis}

Financial regulators have introduced several mechanisms in controlling bank risk-taking behaviour. There are four basic regulatory and supervisory mechanisms emphasised by the Basel Committee and highlighted by the theory of risk-taking behaviour, namely capital requirements (Berger et al., 2016; Holod et al., 2020), asset restrictions (Laeven \& Levine, 2009; Liu et al., 2012; Beck et al., 2006; 2013; Mohsni \& Otchere, 2017), official supervision (Fernández \& González, 2005; Tabak et al., 2016), and private monitoring (BrandaoMarques et al., 2018; Delis et al., 2011). Despite the proliferation of research in banking regulation, there is still ongoing discourse on regulatory policies across countries. Theories have provided inconclusive views on the role of regulation on bank risk. Based on the literature mentioned above, most discussions on the banking regulation theories are skewed towards bank risk in general, aiming to achieve financial stability. Most of the empirical evidence is based on multiple countries, while a few focuses on the individual country like the Netherlands (Bolt \& Tieman, 2004), the U.S. (Beck et al., 2013; Holod et al., 2020), Germany (Berger et al., 2016). These studies mostly focus on credit risk and solvency risk except Holod et al. (2020), who examined market risk, respectively. Nevertheless, as far as this study is concerned, limited studies have examined liquidity risk issues in the Islamic banking industry.

Previous documentation in OIC Islamic banks focuses on liquidity risk determinants. For example, focusing on 16 OIC countries from 1999 to 2013, Amin et al. (2017) found that liquidity risk is determined by cost efficiency, capital, bank specialisation, credit risk, profitability, size, GDP and inflation. Based on a sample comprising of 52 OIC banks (1989 to 2008), Al-Harbi (2017) found that liquidity has a positive relationship with profitability, size, efficiency, off-balance-sheet activities and market capitalisation, and a negative relationship with capital, foreign ownership, credit risk, GDP inflation, monetary policy and deposit insurance. However, the role of regulation on liquidity risk in OIC Islamic banks is not explored in the previous studies.

To account for the importance of regulation on Islamic banks, Alam (2013) and Alam et al. (2018) examined the impact of regulation on risk and efficiency in 11 Islamic banking countries (2006 to 2010) and on the performance 
of 10 Asian and Gulf Cooperation Council (GCC) banks (2006 to 2015), respectively. The findings by Alam (2013) suggest that supervisory power and private monitoring increase the efficiency of Islamic banks. Meanwhile, capital requirements are found to be positively related to technical efficiency and negatively related to the credit risk of Islamic banks. Alam et al. (2018) found that regulation has a positive effect on the performance of Islamic banks in the Asian region. Nevertheless, Alam's works did not specifically emphasise on regulationliquidity risk relationship, which warrants further research.

\section{METHODOLOGY}

\section{The Empirical Model}

The empirical framework for liquidity risk determinants is specified as follows:

$$
\begin{aligned}
L R_{i t}= & \alpha_{i}+\beta_{1} L R_{i t-1}+\beta_{2} \text { reg }+\beta_{3} \text { reg }^{*} I B+\beta_{4} \text { internal }_{i t}+\beta_{5} \text { external }_{i t} \\
& +\beta_{6} \text { cri }+\beta_{7} I B+\varepsilon_{i}
\end{aligned}
$$

Where $L R$ is liquidity risk, which represents NSFR and total loans-to-deposit and short-term funding ratio (LDEP). NSFR is the liquidity requirement proposed in Basel III, which is measured by dividing the available amount of stable funding (ASF) to the required amount of stable funding (RSF), following Gobat et al. (2014) measurements. $L R_{i t-1}$ is the lagged dependent variable. Four regulation indicators are considered to determine the impact of regulation (reg) on liquidity risk: activity restrictions, capital requirements, private monitoring, and supervisory power. We also tested the moderating effect of Islamic banks on the relationship between regulation and liquidity risk to capture the relative impact of regulation between Islamic banks and conventional banks. Additionally, a set of control variables is determined as suggested in the literature (Amin et al., 2017; Berger et al., 2016; Horvath et al., 2014; 2016; Khalib et al., 2016; Chen et al., 2015; Ghenimi \& Omri, 2015; Roman \& Sargu, 2015; Bonfim \& Kim, 2012; Ali, 2012; Angora \& Roulet, 2011). It includes bank-specific factors (internal), i.e., capital, size, credit risk, profitability and macroeconomic factors (external), i.e., market concentration, GDP, inflation). To control the effect of the global crisis and the type of bank on liquidity risk, we include a dummy for the crisis period (cri) and Islamic bank (IB), respectively. $\alpha$ is a bank-specific intercept, $\varepsilon$ is the error term and $i$ and $t$ refer to bank and time, respectively. For more details, Table 1 provides brief descriptions of all variables. 
Table 1

Variable's definition

\begin{tabular}{|c|c|c|c|}
\hline Variable & Definition & Sources & $\begin{array}{l}\text { Expected } \\
\text { relationship }\end{array}$ \\
\hline \multicolumn{4}{|l|}{ Dependent variables } \\
\hline NSFR & $\begin{array}{l}\text { Available stable funding/ } \\
\text { required stable funding }\end{array}$ & BankScope & \\
\hline $\begin{array}{l}\text { Total loans-to-total } \\
\text { deposits and short- } \\
\text { term funding (LDEP) }\end{array}$ & $\begin{array}{l}\ln (\text { net loan/deposit and } \\
\text { short-term funding) } \\
\text { High ratio shows high } \\
\text { liquidity risk. }\end{array}$ & BankScope & \\
\hline \multicolumn{4}{|l|}{ Independent variables } \\
\hline \multicolumn{4}{|l|}{ Internal factors } \\
\hline Credit risk (LLR) & $\begin{array}{l}\text { Loan loss reserve/gross } \\
\text { loans }\end{array}$ & BankScope & - \\
\hline Capital (ETA) & Equity/total assets & BankScope & $+/-$ \\
\hline Profitability (ROA) & Net income/total assets & BankScope & + \\
\hline Size $(\operatorname{lnTA})$ & $\ln$ (total assets) & BankScope & $+/-$ \\
\hline \multicolumn{4}{|l|}{ External factors } \\
\hline Competition (Com) & $\begin{array}{l}\ln (\mathrm{HHI} \text { the sum of the } \\
\text { aquares of the market } \\
\text { shares of each individual } \\
\text { bank assets })\end{array}$ & BankScope & $+/-$ \\
\hline GDP growth (GDP) & Real GDP growth rate & WDI & + \\
\hline Inflation (Inf) & Inflation rate & WDI & - \\
\hline \multicolumn{4}{|l|}{ Regulation measures } \\
\hline $\begin{array}{l}\text { Activity Restrictions } \\
\text { (AR) }\end{array}$ & $\begin{array}{l}\text { Restrictions on banking } \\
\text { activities in securities, } \\
\text { insurance, real estate } \\
\text { activities, and ownership } \\
\text { of non-financial firms. } \\
\text { The index value is } 0 \text { to } 4 \text {, } \\
\text { high value indicates higher } \\
\text { level of restrictions. }\end{array}$ & $\begin{array}{l}\text { World Bank's } 2013 \\
\text { Regulation and } \\
\text { Supervisory Database } \\
\text { (Barth et al., 2013) }\end{array}$ & - \\
\hline
\end{tabular}


Table 1 (continued)

\begin{tabular}{|c|c|c|c|}
\hline Variable & Definition & Sources & $\begin{array}{l}\text { Expected } \\
\text { relationship }\end{array}$ \\
\hline $\begin{array}{l}\text { Capital Requirements } \\
\text { (CR) }\end{array}$ & $\begin{array}{l}\text { Includes regulatory capital } \\
\text { and capital from assets other } \\
\text { than cash or government } \\
\text { securities and borrowed } \\
\text { funds. The index value is } 0 \\
\text { to } 8 \text {; high value indicates } \\
\text { rigid capital requirements. }\end{array}$ & $\begin{array}{l}\text { World Bank's } 2013 \\
\text { Regulation and } \\
\text { Supervisory Database } \\
\text { (Barth et al., 2013) }\end{array}$ & $+/-$ \\
\hline $\begin{array}{l}\text { Private Monitoring } \\
(\mathrm{PM})\end{array}$ & $\begin{array}{l}\text { The degree of information } \\
\text { disclosure and market } \\
\text { discipline by private } \\
\text { investors on banks. } \\
\text { The index value is } 0 \text { to } 8, \\
\text { high value indicates greater } \\
\text { private monitoring on banks. }\end{array}$ & $\begin{array}{l}\text { World Bank's } 2013 \\
\text { Regulation and } \\
\text { Supervisory Database } \\
\text { (Barth et al., 2013) }\end{array}$ & - \\
\hline $\begin{array}{l}\text { Supervisory Power } \\
\text { (SP) }\end{array}$ & $\begin{array}{l}\text { Regulatory empowerment } \\
\text { to intervene in banking } \\
\text { decisions like organisational } \\
\text { structure, to take disciplinary } \\
\text { actions on top management } \\
\text { and directors, shareholders, } \\
\text { and auditors. The index is } 0 \\
\text { to } 14 \text {; high value indicates } \\
\text { greater supervisory power. }\end{array}$ & $\begin{array}{l}\text { World Bank's } 2013 \\
\text { Regulation and } \\
\text { Supervisory Database } \\
\text { (Barth et al., 2013) }\end{array}$ & - \\
\hline \multicolumn{4}{|l|}{ Dummy variables } \\
\hline Islamic bank (IB) & $\begin{array}{l}\text { Dummy that takes the value } \\
\text { of one for Islamic bank and } 0 \\
\text { for conventional bank }\end{array}$ & Own & + \\
\hline Crisis (Cr) & $\begin{array}{l}\text { Dummy crisis that is equal } \\
\text { to one for the crisis period } \\
\text { during 2008-2009 and } 0 \text { for } \\
\text { other years }\end{array}$ & Own & + \\
\hline $\mathrm{IB} * \mathrm{AR}$ & $\begin{array}{l}\text { Interactive dummy Islamic } \\
\text { bank*Asset restrictions }\end{array}$ & Own & - \\
\hline $\mathrm{IB} * \mathrm{CR}$ & $\begin{array}{l}\text { Interactive dummy Islamic } \\
\text { bank* Capital requirements }\end{array}$ & Own & - \\
\hline IB*PM & $\begin{array}{l}\text { Interactive dummy Islamic } \\
\text { bank*Private monitoring }\end{array}$ & Own & - \\
\hline $\mathrm{IB} * \mathrm{SP}$ & $\begin{array}{l}\text { Interactive dummy Islamic } \\
\text { bank* Supervisory power }\end{array}$ & Own & - \\
\hline
\end{tabular}




\section{Data and Sample}

The study employs secondary data from BankScope, involving 245 conventional banks and 681 Islamic banks from selected 14 OIC countries, namely, Bahrain, Bangladesh, Egypt, Indonesia, Jordan, Kuwait, Malaysia, Pakistan, Qatar, Saudi Arabia, Tunisia, Turkey, the United Arab Emirates and Yemen. Macroeconomic variables (inflation, GDP) are collected from World Development Indicators. We obtain banking regulation data from Barth et al. (2001; 2006; 2008; 2013) World Bank database to capture Basel III's pillars on bank regulation and supervision. All dataset includes 313 banks, ranging from 2000 to 2017. The screening criteria of the sample banks are:

1. Include only commercial banks and full-fledged Islamic banks.

2. Exclude banks with missing bank-specific variables.

3. Exclude banks that have less than three consecutive years of observations.

Our sample starts from 2000 because of the presence of OIC Islamic banks that are more pronounced after 2000. The data end in 2017 because it is the latest data that we manage to collect due to the availability of the World Bank's 2013 Regulation and Supervisory database until 2013, and the fact that most of the regulatory measure is constant in average for five years. For robustness check, we split the sample into two sub-periods, namely, 2000-2009 and 20102017.

\section{RESULTS AND DISCUSSIONS}

Table 2 details the descriptive statistics of variables. In general, it shows that Islamic banks have higher liquidity risk than conventional banks, reflected by lower NSFR and higher LDEP. Interestingly, during 2010-2017, banks have higher liquidity risk than the years before (2000-2009), though all banks reached more than $100 \%$ threshold required for NSFR. All three regulation variables (activity restrictions, private monitoring and supervisory power) are lower during the 2010-2017 sub-period compared to 2000-2009. Whereas capital requirements are higher during 2010-2017 than the 2000-2009 period. 


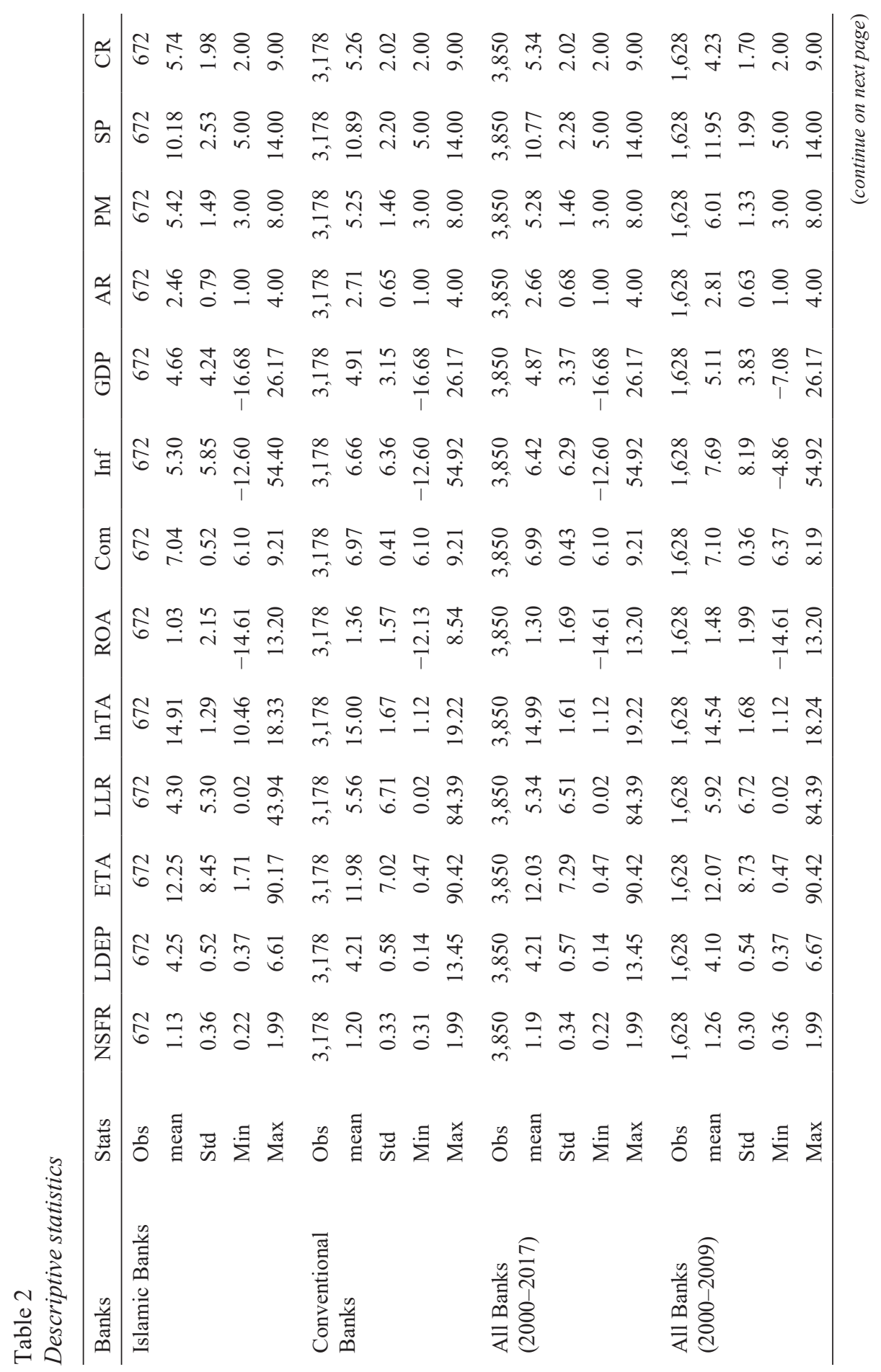




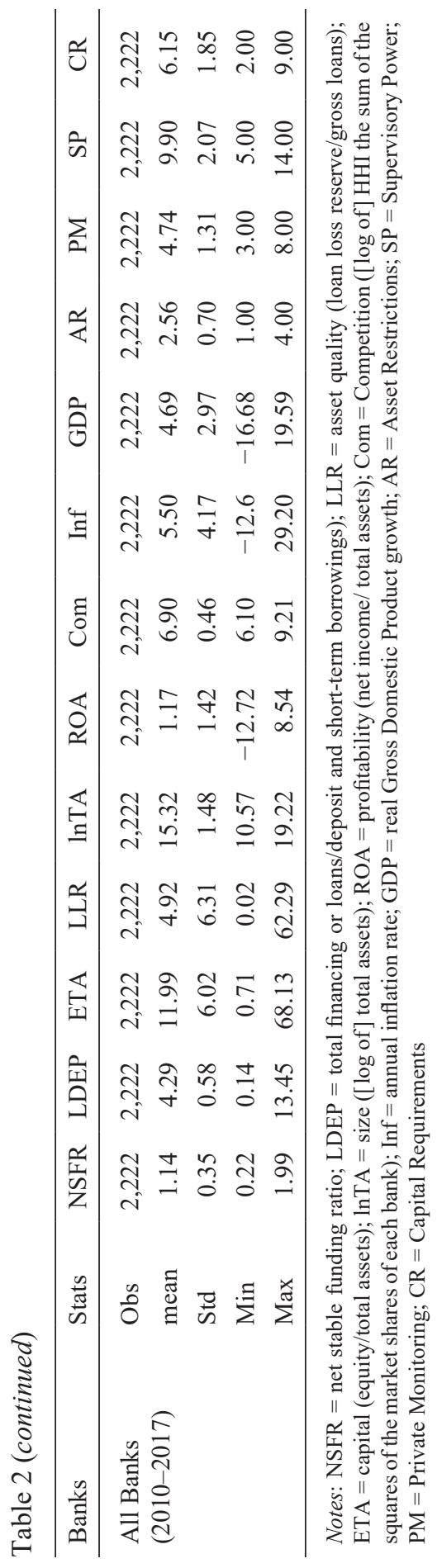


Based on the average of banking regulatory and supervisory measures in Table 3, Indonesia has the highest level of restrictions on banking activities and Kuwait has the lowest restrictions. Saudi Arabia has the strongest supervisory control and private monitoring, while Yemen and Tunisia have the least supervisory and private control on banking activities, respectively. In terms of capital standards, Pakistan has the highest requirements, and Egypt has the lowest.

Table 3

Regulation and supervision index (2000-2017)

\begin{tabular}{lcccc}
\hline Country & AR & SP & PM & CR \\
\hline Bangladesh & 3.17 & 10.71 & 4.51 & 4.42 \\
Egypt & 2.54 & 12.00 & 6.21 & 3.77 \\
Indonesia & 3.32 & 11.64 & 5.02 & 4.00 \\
Jordan & 2.72 & 7.20 & 5.60 & 5.39 \\
Kuwait & 1.87 & 9.84 & 7.31 & 5.88 \\
Malaysia & 2.37 & 10.92 & 5.85 & 5.02 \\
Pakistan & 2.93 & 12.21 & 6.83 & 7.10 \\
Qatar & 2.04 & 8.93 & 6.46 & 4.32 \\
Saudi Arabia & 2.79 & 13.48 & 7.52 & 5.21 \\
Tunisia & 2.57 & 11.00 & 3.24 & 4.53 \\
Turkey & 2.19 & 12.48 & 5.51 & 4.00 \\
UAE & 2.64 & 10.44 & 5.97 & 5.00 \\
Yemen & 2.50 & 6.00 & 5.00 & 5.00 \\
\hline
\end{tabular}

Notes: $\mathrm{AR}=$ Asset Restrictions; $\mathrm{SP}=$ Supervisory Power; $\mathrm{PM}=$ Private Monitoring; $\mathrm{CR}=$ Capital Requirements

Table 4 reports the liquidity risk determinants results based on the panel system GMM models for NSFR and LDEP for full sample (2000-2017). The inference of the alternative liquidity risk measures (NSFR and LDEP) should be explained with caution since these two variables contradict the liquidity risk interpretations. While high NSFR indicates low liquidity risk, high LDEP implies high liquidity risk and vice versa. The significant positive effect of lagged dependent variable $\left(\mathrm{NSFR}_{t-1}, \mathrm{LDEP}_{t-1}\right)$ at $1 \%$ in all models substantiates the justification of the GMM technique, as there are dynamic specifications in the models. It shows that previous liquidity influences current liquidity and takes time to adjust. In other terms, liquidity policy in banking is determined based on experience in the previous year. The finding is in line with previous studies (Amin et al., 2107; Angora \& Roulet, 2011; Horvath et al. 2014; 2016). 


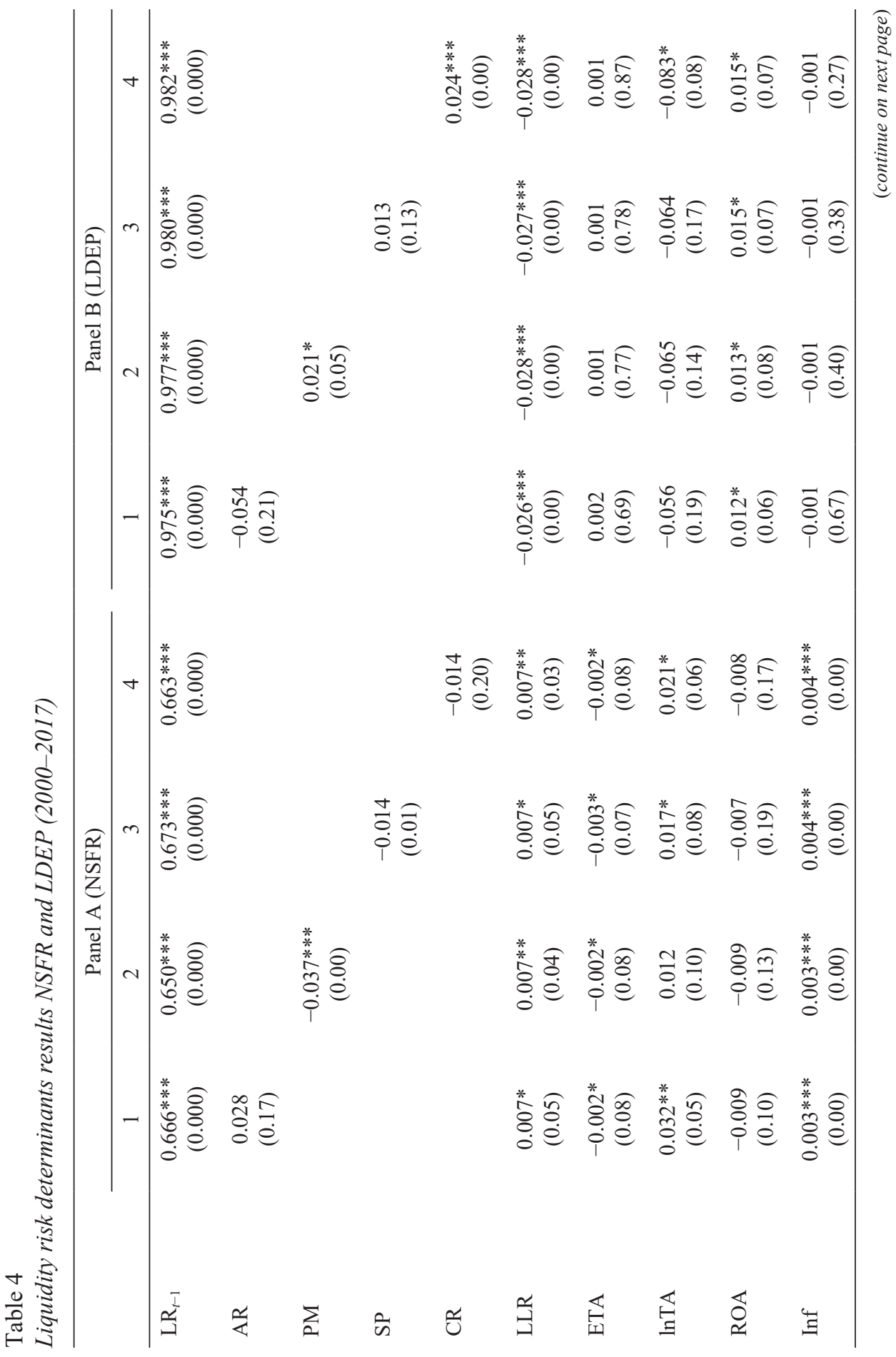




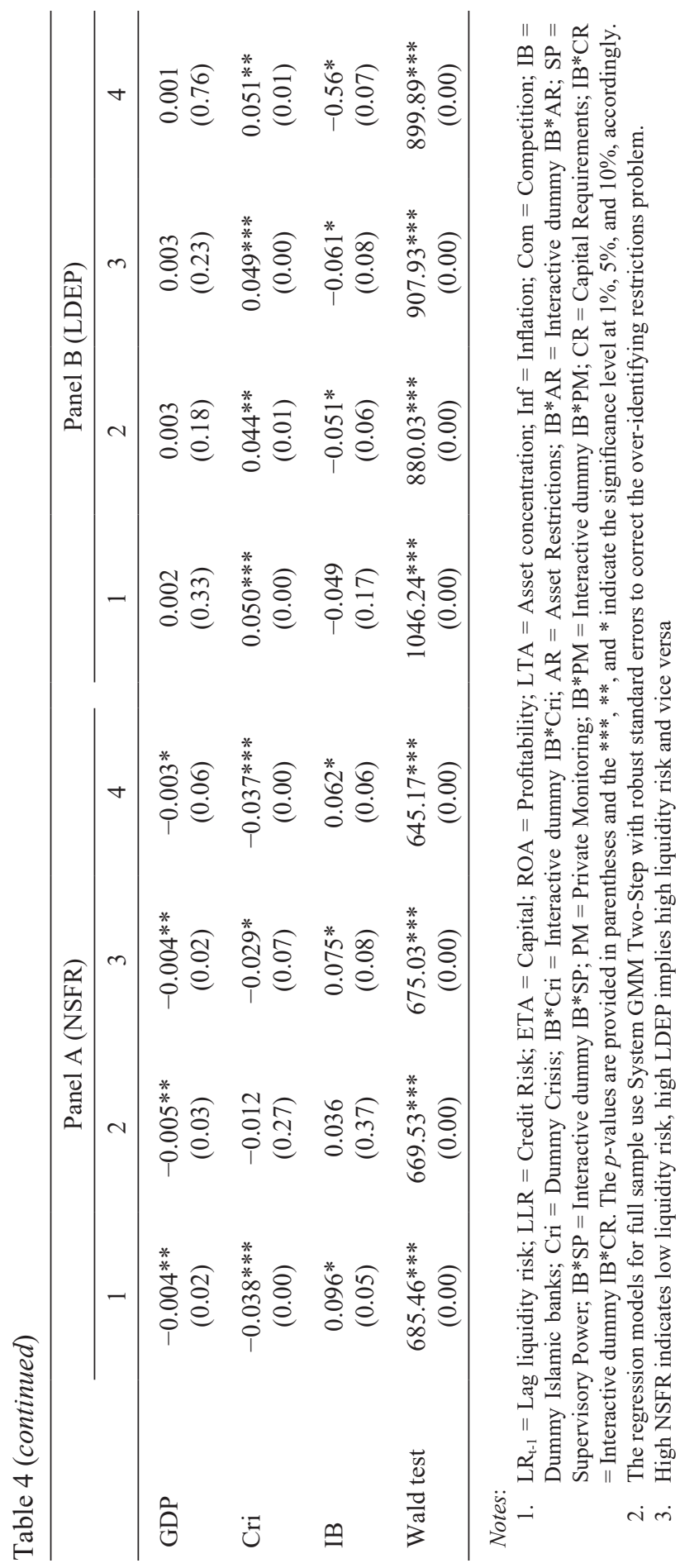


We found that activities restriction (AR) has no significant effect on liquidity risk. For private monitoring (PM), it has a positive effect on liquidity risk, as shown by a significant negative (positive) coefficient in the NSFR (LDEP) models, respectively. Our findings are impliedly consistent with Delis et al. (2011), suggesting that empowering public monitoring through accounting and auditing systems would increase bank productivity, which encourages risk-taking incentives. Due to competitive business environments, high productivity banks engage in high-risk projects to improve profitability, which leads to high liquidity risk exposure. However, we found limited evidence to support this positive PM-liquidity risk relationship. It could be explained by the nature of developing OIC countries that exhibit high asymmetric information, causing public information differs from internal information, particularly banking institutions. Furthermore, the non-uniformity of accounting and auditing practice across OIC member countries would potentially implicate less effectiveness of private monitoring to monitor bank risk. Fernández and González (2005) opined that since regulatory devices such as activity restrictions and capital requirements have restricted bank activities, it may discourage monitoring by depositors and shareholders and thereby minimise the effectiveness of accounting and auditing practices.

The effect of supervisory power (SP) on liquidity risk is positive, as shown by the statistically negative coefficient for NSFR model. It is consistent with the findings in Barth et al. (2001), indicating that strong supervision increases bank risk, especially in the case of powerful government-linked official supervision in developing countries (Barth et al., 2003), OIC banks are not exceptional. The reason could be due to the conflicting interest of supervisors that in favour of political agenda instead of the interest to supervise banks from market failure. However, the results show mild evidence to support the findings by Barth et al. (2003). Our findings are in line with Laeven and Majnoni (2003), suggesting that the effect of a of a supervisory regime might not be significant, especially for transition economies, ${ }^{1}$ where leading banks may influence politicians and supervisors to pursue banks' objectives rather than to meet the society's interest. Besides, Barth et al. (2004) argued that the important role of supervisory power might not hold across different levels of political openness (i.e., the country where the media is independent of government intervention). In parallel with OIC countries, the different development levels in terms of market power and political openness could potentially contribute to the insignificant results. 
For capital requirements (CR), the effect is significantly positive on liquidity risk, as reflected in the LDEP model. It is in line with the findings in Altunbas et al. (2018), which suggest that highly capitalised banks have higher risk-bearing capacity which incentivise banks to engage in high risk taking behaviour. In a highly competitive market where Islamic banks operate side-byside with conventional banks, OIC banks tend to take riskier lending to boost profitability and to maximise the shareholders' wealth in compensating the cost of holding capital due to franchise value trade-off.

Table 5 provides the results of the interaction of regulation variables and Islamic bank dummy to examine the differential impact of regulation between Islamic banks and conventional banks. The finding of $\mathrm{IB}^{*} \mathrm{CR}$ indicates that the marginal impact of $\mathrm{CR}$ is lower for Islamic banks than conventional banks, as shown by significant $(0.016)$ NSFR and $(-0.002)$ LDEP. We found that Islamic banks are less sensitive to the effect of $\mathrm{CR}$ on liquidity risk compared to conventional banks, as indicated by the significant positive (negative) coefficient (IB*CR) in NFSR (LDEP) models. It can be explained by the inferiority of Islamic banks compared to conventional peers in terms of relatively restricted risk management tools and shallow secondary markets to manage liquidity risk (Ramzan \& Zafar, 2014; Amin et al., 2017). Islamic banks tend to hold excess capital to absorb losses and are less affected by the regulatory capital requirements. The impact of PM and SP on liquidity risk is indifferent between Islamic and conventional banks. The indifferent impact of PM and SP on liquidity risk in both banks could be linked with the standard disclosures of the banking system across OIC countries.

For robustness check, Table 6 presents the results for subsample 20002009 and 2010-2017. Most of the sub-sample results are consistent with the full sample results. Taken together, regulation has a limited impact on bank liquidity risks. Our findings show that only $31 \%$ (15 out of 48 models) of the estimation models are significant to relate regulation and liquidity risks. Of these regulation variables that are significant, CR supports the value creation of regulation variables by reducing banks' liquidity risks. In contrast, the PM and SP support the agency costs of regulation, leading to higher liquidity risks. The findings imply that the existing regulatory measures are insufficient to discipline banks in managing liquidity risk. Therefore, our findings support the introduction of new liquidity regulation in Basel III proposal, which is missing in Basel II. Al-Harbi (2017) argued that liquidity risk was considered a secondary risk before the liquidity crisis in 2008-2009 by the regulators that lead to the introduction of liquidity risk requirements in Basel III. 
Syajarul Imna Mohd Amin et al.

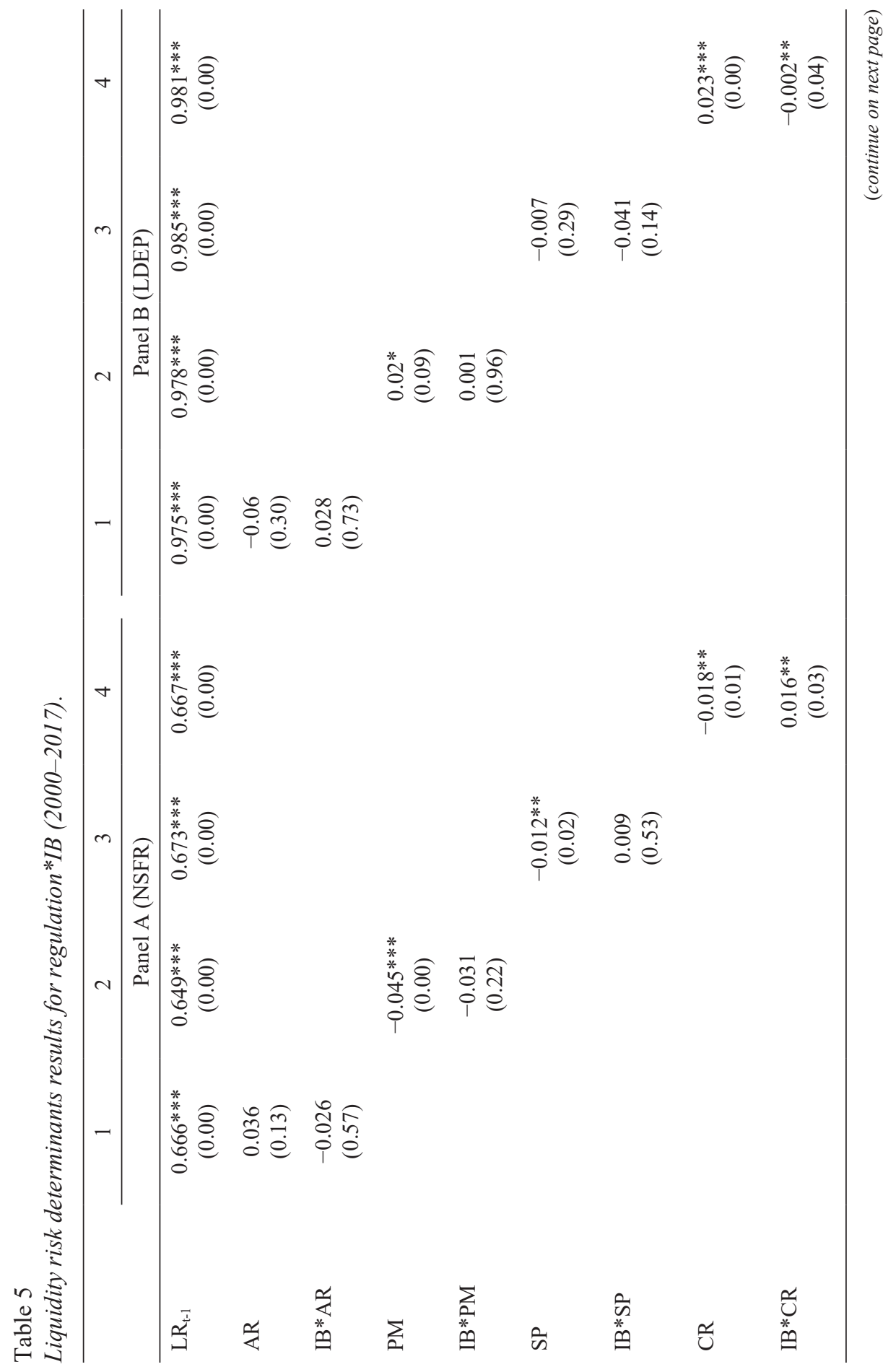


Liquidity Risk and Regulation in Banking
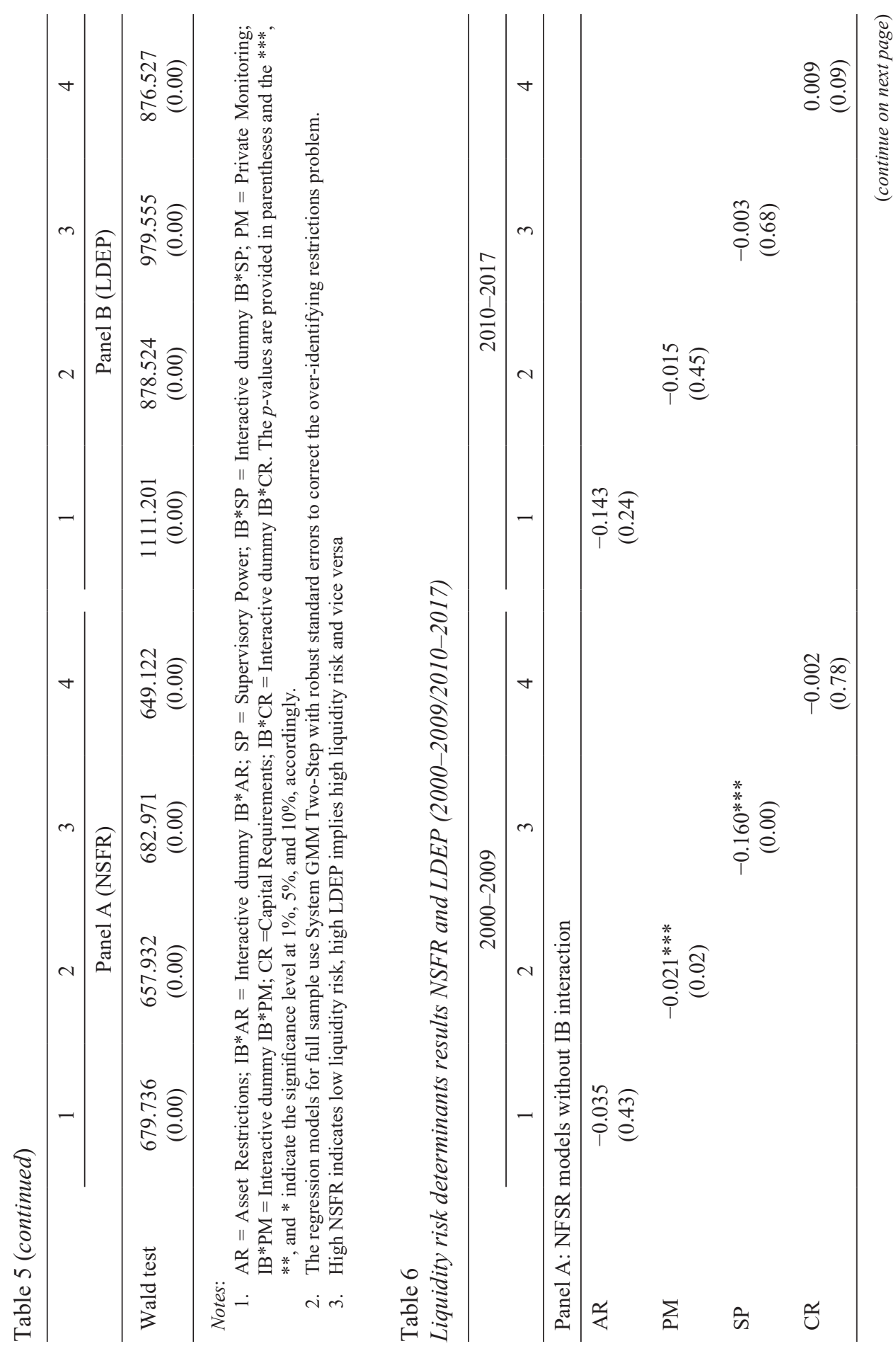
Syajarul Imna Mohd Amin et al.

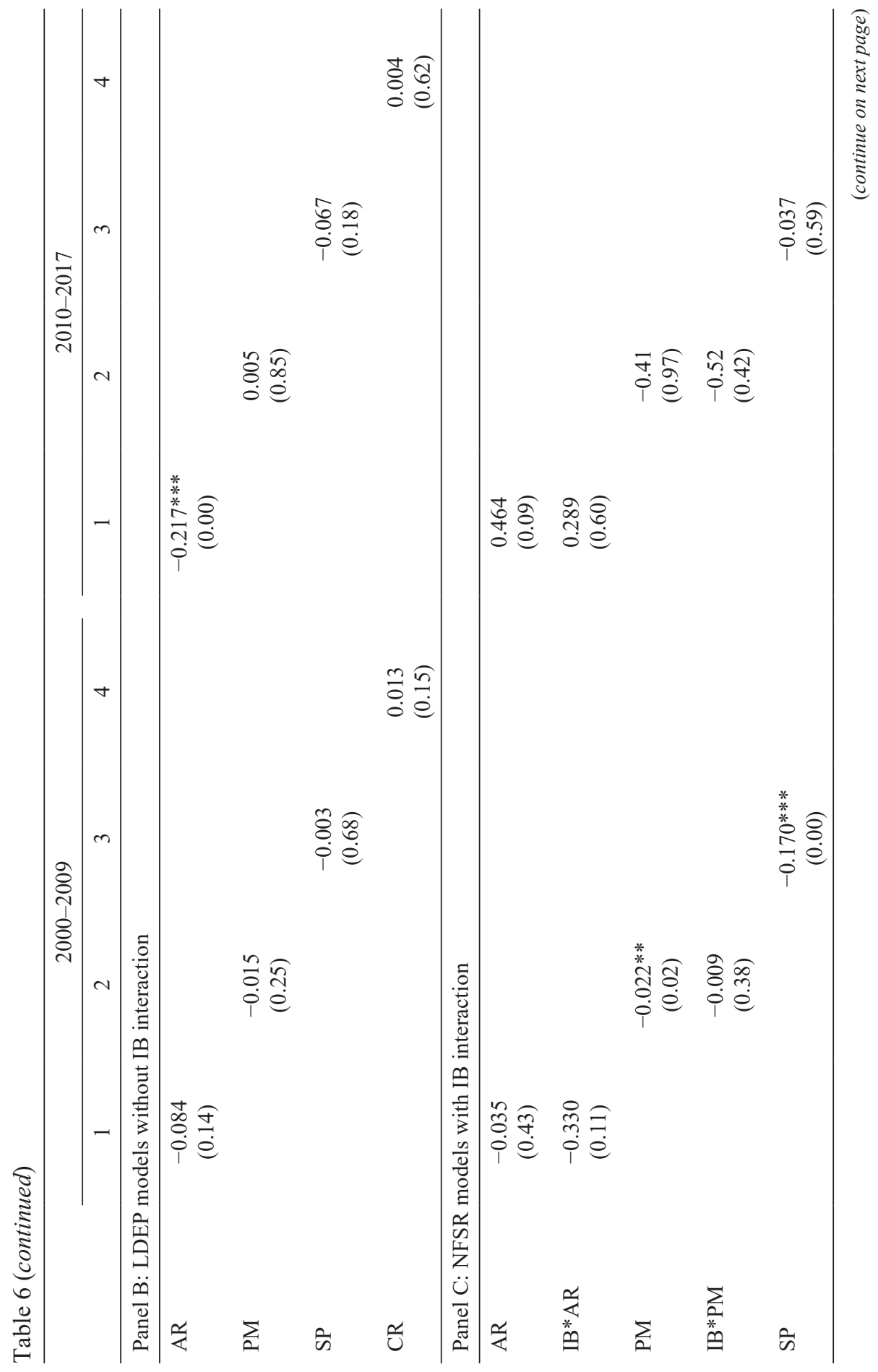


Liquidity Risk and Regulation in Banking

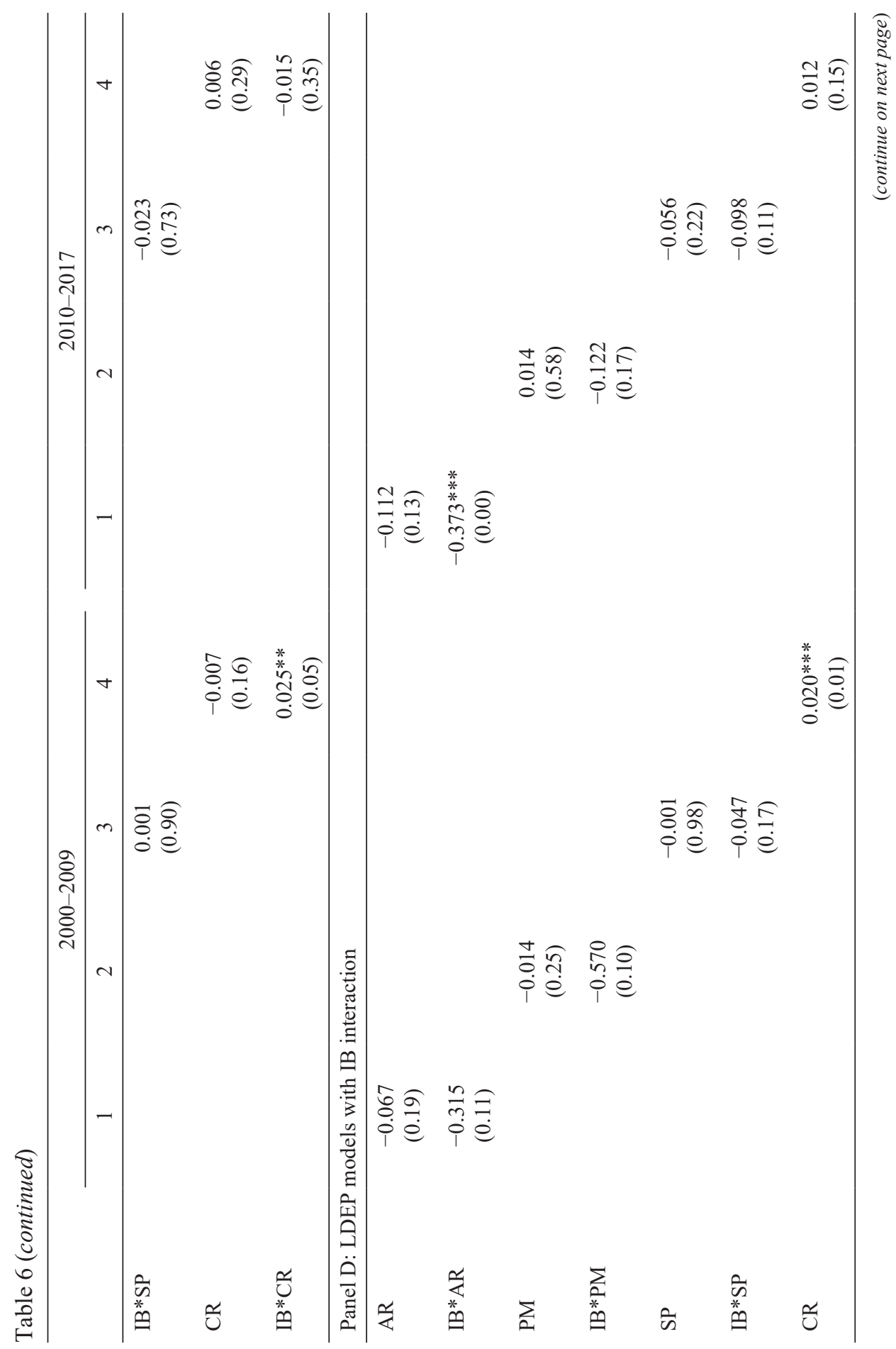


Syajarul Imna Mohd Amin et al.

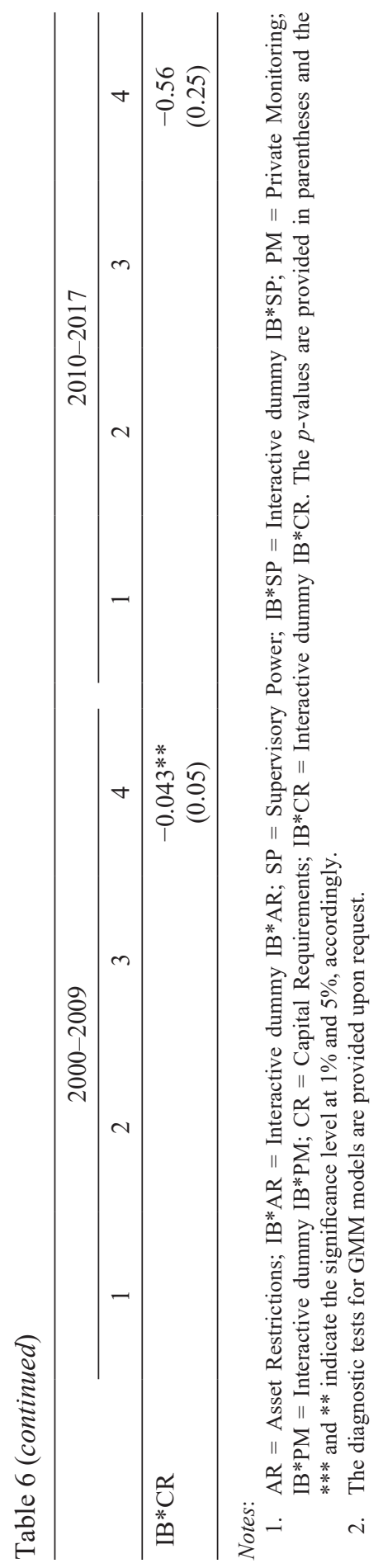


However, despite the regulatory and supervisory framework efforts in OIC countries, the effectiveness of the regulations is flawed by the characteristic of developing OIC economies that lack many aspects, including infant fiscal legislation, fragmented and uncoordinated Shariah supervision, and inconsistency of ruling across jurisdictions. Furthermore, equity-based products in Islamic banking increase complexity, where a bank takes on both the financier and contractor's role, which intensifies the challenge to manage liquidity risk than conventional banks.

For credit risk $(L L R)$, our findings are consistent with several studies (Amin et al., 2017; Angora \& Roulet, 2011; Berger et al., 2016; Horvath et al., 2014), indicating a negative impact on liquidity risk. Bank with numerous cases of defaults in previous records (poor asset quality) has to be cautious and tighten the terms of credit that result in reduced lending opportunities. Moreover, since the bank has allocated a high amount of reserve to absorb loan losses, liquidity issues arising from uncollectable payments in the future have been at least addressed. For capital (ETA), the findings align with risk absorption theory, indicating a positive relationship with liquidity risk (Amin et al., 2017; Berger et al., 2016; Chen et al., 2015; Horvath et al., 2016; Roman \& Sargu, 2015). The theory predicts that banks with substantial capital often aim for high profit (high risk) investments since they have a high capacity to absorb the losses. Therefore, a high capitalised bank with risky portfolios will be exposed to high liquidity risk.

The impact of size ( $\operatorname{LnTA}$ ) on liquidity risk is found to be significantly negative. Consistent with previous studies (Angora \& Roulet, 2011; Horvath et al., 2014), it suggests that large banks, associated with high reputation, economies of scale, and sophistication in risk management, can formulate better decisions in managing liquidity risk. In contrast for small banks, they have fewer resources (fund) to expand credit supply. Like several studies (Angora \& Roulet, 2011; Berger et al., 2016; Bonfim \& Kim, 2014), profit (ROA) has no significant effect on liquidity risk. It could be explained by the impact of economic uncertainties and market intervention by the policymaker, which has more weight on determining bank liquidity policies than financial capability.

Based on the macro and market factors results, the impact of inflation (Inf) on liquidity risk is negative (Amin et al., 2017; Ghenimi \& Omri, 2015). It indicates that inflation increases bank costs, such as increasing nominal interest rates and diminishing collateral value, thus decreasing realised profit. Although the bank may transfer the cost by increasing the profit rate on lending, the bank will be exposed to problem loans, affecting liquidity in banking. Therefore, during inflation, the bank prefers to hold liquid assets rather than offering 
loans. GDP poses a positive impact on liquidity risk. The positive relationship confirms the finding in Angora and Roulet (2011), suggesting that demand for credits increases as businesses perform well during an economic boom, resulting in increased financing offerings. However, no significant relationship is found between competition ( $\mathrm{Com}$ ) and liquidity risk. As Amin et al. (2017) opined, the explanations might have to do with the characteristics of the sampled developing countries with dual banking systems associated with high transaction costs and no economies of scale, making no comparative advantage in achieving a high return. Therefore, market power is less effective in affecting banking activities, including liquidity decisions.

The finding of Cri support on the important effect of the crisis on liquidity risk as in (Amin et al., 2017). It shows that OIC banks have higher liquidity risk during the global financial crisis. In comparison, Islamic banks have lower liquidity risks than conventional banks, which is inconsistent with Ali (2012). The result may be explained by the infancy stage of Islamic banking development that lacks many aspects such as few liquidity instruments and shallow money and secondary markets, forcing Islamic banks to hold more liquidity.

Overall, capital requirements increase banks' value by reducing banks' liquidity risks while private monitoring and supervisory power incur costs, leading to higher liquidity risks. However, the marginal impact capital requirements are more pronounced for conventional banks than Islamic banks. Most of the control variables are found to be significant across all regression specifications in selected regression tables. It shows that liquidity risk increases by the influence of capital, assets concentration, and GDP; and decreases due to poor asset quality, big size and inflation. Moreover, banks are exposed to higher liquidity risk during crisis. Nevertheless, the impact of profitability, competition, and crisis are not significant. The findings also show that Islamic banks have lower liquidity risk than conventional banks.

\section{CONCLUSION AND IMPLICATION}

This study analyses the role of banking regulation on the liquidity risk of 245 conventional banks and 68 Islamic banks from selected 14 OIC countries from 2000-2017 using the dynamic panel GMM technique. In general, the results suggest that capital requirements (CR) are consistent with the value creation of regulation through the reduction in banks' liquidity risk while private monitoring (PM) and supervisory power (SP) align with agency costs of regulation that lead to higher liquidity risks. For Islamic banks, the marginal effect of CR is lesser on 
liquidity risk than their conventional counterparts. However, our findings suggest that regulation has a mild effect on liquidity risk in banking. Only $31 \%$ of the estimation models are significant to relate the important effect or regulation on liquidity risk. The implication of these results concludes that the 'one-size-fitsall' solutions for regulating banks are not reflecting the OIC countries, which feature different country specificities such as financial development, fiscal legislation and interpretation of Shariah laws. Furthermore, the message from these analyses imply that the traditional regulatory measures (i.e., AR, PM, SP, $\mathrm{CR}$ ) are not adequate to regulate liquidity risk management in Islamic banking that is in line with Alam et al. (2018), highlighting that Islamic banking regulations are still in deficiencies. Besides, our findings support the introduction of new liquidity regulation in Basel III proposal, which is missing in Basel II.

For internal factors, the impact of past liquidity, capital, and assets concentration on liquidity risk is positive, while asset quality and size pose a negative effect. For macro and market factors, the impact of GDP and inflation is positive and negative, respectively. Also, liquidity risk is higher during crisis. The findings suggest that Islamic banks have lower liquidity risks than conventional ones. It indicates that Islamic banks have been forced to hold a high liquidity buffer due to the limitations of liquidity management tools and markets. It underscores the critical importance of a proactive role by the government to provide Shariah-compliant financial solutions and instrumental support towards developing Islamic financial instruments and liquidity infrastructures.

The significance of this research is the risk analyses on the OIC's banks and their current level of development despite the liquidity risk management challenges that they are facing. For Islamic banks, the findings serve as a benchmark for measuring the banking policies whether they are in parallel with the current regulatory requirements in enhancing the Islamic banking industry's stability. Thus, policymakers will make more informed decisions on regulation to narrow the liquidity risk, tailoring to the Islamic banks' risk profile. Accordingly, enhanced banking credibility will ensure the confidence of the stakeholders and the public. The shareholders and investors, in particular, will have better updates on their investments (banks) and the risk involved in these sectors. However, the limitation of the study is that most of the sample banks are concentrated in four countries (55\%), namely Indonesia (21\%), Malaysia $(13 \%)$, Bangladesh (11\%), and Turkey (10\%) that may not reflect the OIC banks as a whole. Future research should extend the scope of the research by using a matched sample of Islamic and conventional banks and a more sophisticated approach for better comparative analysis. 


\section{ACKNOWLEDGEMENTS}

The authors appreciate the valuable comments by the anonymous reviewers and the financial support from Yayasan Tun Ismail Mohamed Ali-UKM (YTI-UKM) grant (code: EP-2018-014).

\section{NOTES}

1. Transition economies includes, among others, economic liberalisation towards privatisation to facilitate the movement of private capital and thus, macroeconomic stability like the some of the Third World countries in the sampled study.

\section{REFERENCES}

Alam, N. (2013). Impact of banking regulation on risk and efficiency in Islamic banking. Journal of Financial Reporting and Accounting, 11(1), 29-50. https://doi.org/10.1108/JFRA-03-2013-0010

Alam, N., Zainuddin, S. S. B., \& Rizvi, S. A. R. (2018). Ramifications of varying banking regulations on performance of Islamic banks. Borsa Istanbul Review, 19(1), 49-64. https://doi.org/10.1016/j.bir.2018.05.005

Ali, S. S. (2012). State of liquidity management in Islamic financial institutions. IRTI Working Paper Series, 1433-06.

Altunbas, Y., Binici, M., \& Gambacorta, L. (2018). Macroprudential policy and bank risk. Journal of International Money and Finance, 81, 203-220. https://doi .org/10.1016/j.jimonfin.2017.11.012

Al-Harbi, A. (2017). Determinants of banks liquidity: Evidence from OIC countries. Journal of Economic and Administrative Sciences, 33(2), 164-177. https://doi .org/10.1108/JEAS-02-2017-0004

Amin, S. I. M., Shamser, M., \& Eskandar, M. S. (2017). Does cost efficiency affect liquidity risk in banking? Evidence from selected OIC countries. Jurnal Ekonomi Malaysia, 51(2), 47-62. https://doi.org/10.17576/JEM-2017-5001-5

Angora, A. \& Roulet, C. (2011). Transformation risk and its determinants: A new approach based on Basel III liquidity management framework. Journal of Financial Studies, 9, 147-183.

Barth, J. R., Caprio, J. G., \& Levine, R. (2001). The regulation and supervision of bank around the world: A new database. In R. E. Litan, \& R. Herring (Eds.), Integrating emerging market countries into the global financial system (pp. 183-240). Brooking Institution Press, Brookings-Wharton Papers in Financial Services. https://doi.org/10.1353/pfs.2001.0003

Barth, J. R., Caprio Jr., G., \& Levine, R. (2003). Bank regulation and supervision: Lessons from a new database. In: Macroeconomic stability, financial markets, and economic development (pp. 183-240). Mexico: Banco de Mexico. 
Barth, J., Caprio, G., \& Levine, R. (2004). Bank regulation and supervision: What works best? Journal of Financial Intermediation, 13, 205-248. https://doi.org/10.1016 /j.jfi.2003.06.002

Barth, J., Caprio, G., \& Levine, R. (2006). Rethinking bank supervision and regulation: Until angels govern. Cambridge, UK: Cambridge University Press. https://doi.org/10.1017/CBO9780511753817

Barth, J., Caprio, G. \& Levine, R. (2008). Bank regulations are changing: For better or worse? Comparative Economic Studies, 50(4), 537-563. https://doi.org/10.1057/ ces. 2008.33

Barth, J. R., Lin, C., Ma, Y., Seade, J., \& Song, F. M. (2013). Do bank regulation, supervision and monitoring enhance or impede bank efficiency? Journal of Banking \& Finance, 37(8), 2879-2892. https://doi.org/10.1016/j.jbankfin.2013.04.030

Basel Committee on Banking Supervision (BCBS). (2008). Liquidity risk: Management and supervisory challenges. Retrieved from https://www.bis.org/publ/bcbs136 .pdf

BCBS. (2010). International framework for liquidity risk management, standards and monitoring, Retrieved from https://www.bis.org/publ/bcbs165.pdf

BCBS. (2013). Basel III: The liquidity coverage ratio and liquidity risk monitoring tools. Retrieved from https://www.bis.org/publ/bcbs238.pdf

Beck, T., De Jonghe, O., \& Schepens, G. (2013). Bank competition and stability: Crosscountry heterogeneity. Journal of Financial Intermediation, 22(2), 218-244. https://doi.org/10.1016/j.jfi.2012.07.001

Beck, T., Demirgüç-Kunt, A., Laeven, L., \& Maksimovic, V. (2006). The determinants of financing obstacles. Journal of International Money and Finance, 25, 932-952.

Berger, A. N., \& Bouwman, C. H. (2009). Bank liquidity creation. The Review of Financial Studies, 22(9), 3779-3837. https://doi.org/10.1093/rfs/hhn104

Berger, A. N., Bouwman, C. H., Kick, T., \& Schaeck, K. (2016). Bank liquidity creation following regulatory interventions and capital support. Journal of Financial Intermediation, 26, 115-141. https://doi.org/10.1016/j.jfi.2016.01.001

Bhattacharya, S., \& Thakor, A. (1993). Contemporary banking theory. Journal of Financial Intermediation, 3, 2-50. https://doi.org/10.1006/jfin.1993.1001

Bolt, W., \& Tieman, A. F. (2004). Banking competition, risk and regulation. Scandinavian Journal of Economics, 106(4), 783-804. https://doi.org/10.1111/ j.0347-0520.2004.00388.x

Bonfim, D., \& Kim, M. (2012). Liquidity risk in banking: Is there herding? European Banking Center Discussion Paper No. 452. https://doi.org/10.2139/ssrn.2163547

Brandao-Marques, L., Correa, R., \& Sapriza, H. (2018). Government support, regulation, and risk taking in the banking sector. Journal of Banking \& Finance, 112, 105284.

Chen, T. H., Chou, H. H., Chang, Y., \& Fang, H. (2015). The effect of excess lending on bank liquidity: Evidence from China. International Review of Economics \& Finance, 36, 54-68. https://doi.org/10.1016/j.iref.2014.11.007

Coval, J., \& Thakor, A. (2005). Financial intermediation as a beliefs-bridge between optimists and pessimists. Journal of Financial Economics, 75, 535-569. https://doi.org/10.1016/j.jfineco.2004.02.005 
Cubillas, E., \& González, F. (2014). Financial liberalization and bank risk-taking: International evidence. Journal of Financial Stability, 11, 32-48. https://oi.org/ 10.1016/j.jfs.2013.11.001

Deli, Y. D., \& Hasan, I. (2017). Real effects of bank capital regulations: Global evidence. Journal of Banking and Finance, 82(September), 217-228. https://doi .org/10.1016/j.jbankfin.2016.11.022

Delis, M. D., Molyneux, P., \& Pasiouras, F. (2011). Regulations and productivity growth in banking: Evidence from transition economies. Journal of Money, Credit and Banking, 43(4), 735-764. https://doi.org/10.1111/j.1538-4616.2011.00393.x

Diamond, D., \& Rajan, R. (2000). A theory of bank capital. Journal of Finance, 55, 2431- 2465. https://doi.org/10.1111/0022-1082.00296

Diamond, D. W., \& Rajan, R. G. (2005). Liquidity shortages and banking crises. Journal of Finance, 60(2), 615-647. https://doi.org/10.1111/j.1540-6261.2005 $.00741 . \mathrm{x}$

Fernández, A., \& González, F. (2005). How accounting and auditing systems can counteract risk-shifting of safety nets in banking: Some international evidence. Journal of Financial Stability, 1, 466-500. https://doi.org/10.1016/j.jfs.2005 .07 .001

Fungáčová, Z., Weill, L., \& Zhou, M. (2017). Bank capital, liquidity creation and deposit insurance. Journal of Financial Services Research, 51(1), 97-123. https://doi .org/10.1007/s10693-016-0240-7

Ghenimi, A., \& Omri, M. A. B. (2015). Liquidity risk management: A comparative study between Islamic and conventional banks. Arabian Journal of Business and Management Review, 5(6), 25-30.

Gobat, J., Yanase, M., \& Maloney, J. (2014). The net stable funding ratio: Impact and issues for consideration. IMF Working Paper No. WP/14/106.

Gorton, G., \& Winton, A. (2017). Liquidity provision, bank capital, and the macroeconomy. Journal of Money, Credit and Banking, 49(1), 5-37. https://doi .org/10.1111/jmcb.12367

Hasan, M., \& Dridi, J. (2011). The effects of the global crisis on Islamic and conventional banks: A comparative study. Journal of International Commerce, Economics and Policy, 2(02), 163-200. https://doi.org/10.1142/S1793993311000270

Hellmann, T. F., Murdock, K. C., \& Stiglitz, J. E. (2000). Liberalization, moral hazard in banking, and prudential regulation: Are capital requirements enough? American Economic Review, 90(1), 147-165. https://doi.org/10.1257/aer.90.1.147

Holod, D., Kitsul, Y., \& Torna, G. (2020). Market risk-based capital requirements, trading activity, and bank risk. Journal of Banking \& Finance, 112, 105202. https://doi .org/10.1016/j.jbankfin.2017.08.019

Horvath, R., Seidler, J., \& Weill, L. (2014). Bank capital and liquidity creation: Grangercausality evidence. Journal of Financial Services Research, 45(3), 341-361. https://doi.org/10.1007/s10693-013-0164-4

Horvath, R., Seidler, J., \& Weill, L. (2016). How bank competition influences liquidity creation. Economic Modelling, 52, 155-161. https://doi.org/10.1016/j.econmod .2014 .11 .032 
Islamic Financial Services Board (IFSB). (2008). Technical note on issues strengthening liquidity management of IIFS: The development of Islamic money market. Retrieved from https://www.ifsb.org/download.php?id=4377\&lang=English \&pg=/published.php

IFSB. (2012). Guiding principles on liquidity risk management for institutions offering Islamic financial services (excluding Islamic insurance (Takaful) institutions and Islamic collective investment schemes). Retrieved from https://www.ifsb .org/download.php?id=4368\&lang=English\&pg=/published.php

IFSB. (2013). Revised Capital Adequacy Standard for IIFS excluding Islamic insurance (takaful) institutions and Islamic collective investment schemes). Retrieved from https://www.ifsb.org/download.php?id=4370\&lang=English\&pg=/published .php

Keeley, M. C. (1990). Deposit insurance, risk, and market power in banking. The American Economic Review, 80(5), 1183-1200.

Khalib, M., Abdul Rahman, A., \& Janor, H. (2016). Impak kecekapan kos terhadap risiko kecairan dalam institusi perbankan di Malaysia. Jurnal Pengurusan, 47, 67-79. https://doi.org/10.17576/pengurusan-2016-47-06

Laeven, L., \& Levine, R. (2009). Bank governance, regulation and risk taking. Journal of Financial Economics, 93(2), 259-275. https://doi.org/10.1016/ j.jfineco.2008.09.003

Laeven, L., \& Majnoni, G. (2003). Loan loss provisioning and economic slowdown: Too much, too late? Journal of Financial Intermediation, 12, 178-197. https://doi.org/10.1016/S1042-9573(03)00016-0

Li, S. (2019). The impact of bank regulation and supervision on competition: Evidence from emerging economies. Emerging Markets Finance and Trade, 55(10), 2334-2364. https://doi.org/10.1080/1540496X.2018.1547191

Liu, H., Molyneux, P., \& Nguyen, L. H. (2012). Competition and risk in South East Asian commercial banking. Applied Economics, 44(28), 3627-3644. https://doi.org/10.1080/00036846.2011.579066

Mohsni, S., \& Otchere, I. (2018). Does regulatory regime matter for bank risk taking? A comparative analysis of US and Canada. Journal of International Financial Markets, Institutions and Money, 53, 1-16. https://doi.org/10.1016/j.intfin .2017 .08 .006

Otero González, L., Ashour, S. O., Redondo-López, J. A., \& Rodríguez Gil, L. I. (2018). Country risk, regulation, and liquidity transformation in Palestine and neighboring countries. Emerging Markets Finance and Trade, 54(6), 1375-1390. https://doi.org/10.1080/1540496X.2017.1285224

Posner, R. A. (1974). Theories of economic regulation (No. w0041). National Bureau of Economic Research.

Ramzan, M., \& Zafar, M. I. (2014). Liquidity risk management in Islamic banks: A study of Islamic banks of Pakistan. Interdisciplinary Journal of Contemporary Research in Business, 5(12), 199-215.

Repullo, R. (2004). Capital requirements, market power, and risk-taking in banking. Journal of Financial Intermediation, 13(2), 156-182. https://doi.org/10.1016/ j.jfi.2003.08.005 
Roman, A., \& Sargu, A. C. (2015). The impact of bank-specific factors on the commercial banks liquidity: Empirical evidence from CEE countries. Procedia Economics and Finance, 20(15), 571-579. https://doi.org/10.1016/S2212-5671(15)00110-0

Shleifer, A., \& Vishny, R. (1998). The grabbing hand: Government pathologies and their cures. Cambridge, UK: Harvard University Press, Cambridge.

Standing Committee for Economic and Commercial Cooperation of the Organization of the Islamic Cooperation (COMCEC) (2018). Financial outlook 2018. Retrieved from http://www.comcec.org/en/wpcontent/uploads/2018/11/2018 -FIN-OUT.pdf

Stigler, G. J. (1971). The theory of economic regulation. Bell Journal of Economics, 2, 3-21. https://doi.org/10.2307/3003160

Tabak, B. M., Fazio, D. M., Karine, C. D. O., \& Cajueiro, D. O. (2016). Financial stability and bank supervision. Finance Research Letters, 18, 322-327. https://doi.org/ 10.1016/j.frl.2016.05.008

Von Thadden, E. (2004). Bank capital adequacy regulation under the new Basel accord. Journal of Financial Intermediation, 13, 90-95. https://doi.org/10.1016/ j.jfi.2003.04.002

Zheng, C., Sarker, N., \& Nahar, S. (2017). Bank disclosures and their impact on credit risk: Evidence from Bangladesh. Asian Economic and Financial Review, 7(12), 1211. https://doi.org/10.18488/journal.aefr.2017.712.1211.1226 